\title{
PENINGKATAN KREATIVITAS, EFEKTIVITAS, DAN MINAT SISWA DALAM PEMBELAJARAN MENULIS NASKAH DRAMA DENGAN MODEL PEMBELAJARAN BERBASIS MASALAH
}

\author{
Nina Fatmawati \\ Universitas Suryakancana, Cianjur \\ fnin.nina@gmail.com
}

\begin{abstract}
This article describes the improvement of students' creativity in learning to write drama script with Problem-Based Learning model (PBM). The research method used is Classroom Action Research. The results showed that students 'creativity, learning effectiveness, and students' interest experienced improvement in each cycle. The average value of student creativity cycle I 75,95, cycle II 86,59, and at cycle III 95,45. Based on the KKM determined that 75, cycles I, 19 students (43.18\%) is not complete and 25 students (56.82\%) thorough, cycle II, 36 students $(81.82 \%)$ complete and 8 students $(18.18 \%)$ is incomplete, and cycle III of all students is complete. Then, the effectiveness of learning also increases. The average value of teacher activity cycle I 2.05 (enough), cycle II 3.27 (good), and in cycle III 3.82 (very good). The average value of student activity in cycle I 2.05 (enough), on cycle II 3 (good), and on cycle III 3.68 (very good). In addition, student interest in learning also increased. The average score of student interest in cycle I 78.92 began to grow (MB), the average value of student interest questionnaire in cycle II $85.91 \mathrm{MB}$, and the average value of student interest questionnaire in cycle III 92.39 with the information already entrust (SM).
\end{abstract}

Keywords: Writing drama script, creativity, effectiveness, interest.

\section{PENDAHULUAN}

Menulis naskah drama merupakan salah satu kompetensi dasar yang perlu dikuasai siswa SMA/MA dalam pembelajaran di sekolah, khususnya pembelajaran bahasa Indonesia. Menurut Waluyo (2001:2) "Drama naskah dapat diberi batasan sebagai salah satu jenis karya sastra yang ditulis dalam bentuk dialog yang didasarkan atas konflik batin dan mempunyai kemungkinan dipentaskan." Ciri yang paling menonjol dari naskah drama adalah cerita yang dibangun dalam naskah drama disajikan dalam bentuk dialog antara tokoh-tokohnya.

Dialog merupakan unsur yang paling penting dalam naskah drama. Begitu pentingnya dialog dalam naskah drama, sehingga tanpa kehadiran dialog suatu karya sastra tidak dapat digolongkan sebagai naskah drama. Hal inilah yang membedakan naskah drama dengan jenis karya sastra yang lain.

Meskipun menulis naskah drama merupakan salah satu kompetensi dasar yang perlu dimiliki dan dicapai siswa SMA/MA dalam pembelajaran di sekolah, khususnya pembelajaran bahasa Indonesia, tetapi kenyataan di lapangan menunjukkan bahwa naskah drama yang dihasilkan siswa masih belum optimal. Hal tersebut terjadi karena dalam pelaksanaan pembelajarannya guru cenderung lebih berorientasi pada teori dan juga ranah kognitif siswa, tanpa mem-perhatikan kreativitas siswa.

Selain itu, dalam pelaksanaan pembelajaran menulis naskah drama, guru cenderung lebih menitikberatkan siswa pada arahan-arahan secara verbal agar siswa dapat mengembangkan kreativitasnya, sehingga pada saat belajar siswa tidak merasakan adanya 
sesuatu yang dapat merangsang kreativitas mereka dapat tumbuh.

Kurangnya perhatian guru terhadap kreativitas siswa mengakibatkan kreativitas siswa dalam pembelajaran menulis naskah drama masih belum optimal. Kenyataan di lapangan menunjukkan bahwa masih banyak siswa yang merasakan kesulitan dalam menulis naskah drama. Banyak siswa yang mengeluhkan bahwa mereka kesulitan dalam menemukan ide ketika akan menulis naskah drama dan ketika menemukan ide siswa pun kesulitan dalam menuangkan ide yang telah dimilikinya ke dalam naskah drama yang akan dibuatnya. Selain itu, naskah drama yang dihasilkan siswa pun kurang menggugah daya emotif pembaca karena cenderung dibuat asal-asalan.

Permasalahan mengenai kreativitas siswa dalam pembelajaran menulis naskah drama pun berakibat pada kurangnya minat siswa dalam pembelajaran menulis naskah drama. Mereka beranggapan bahwa daripada harus merasakan kesulitan dalam menulis naskah drama lebih baik langsung menonton pementasan drama atau langsung memerankan salah satu tokoh yang ada dalam naskah drama.

Apabila kesenjangan yang telah dikemukakan di atas tidak segera ditangani ataupun tidak dicari pemecahannya, kreativitas siswa dalam pembelajaran menulis naskah drama tidak akan berkembang. Terkait dengan hal itu, kreativitas siswa dalam pembelajaran menulis naskah drama perlu ditingkatkan karena pada dasarnya setiap individu memiliki kreativitas, kemampuan untuk mencipta, kemampuan untuk membuat sesuatu, yang menjadi persoalannya apakah kreativitas itu akan ditingkatkan atau dibiarkan begitu saja. Seperti yang dikemukakan Supriadi (1994:15) dalam salah satu asumsinya mengenai kreativitas, yaitu "setiap orang memiliki kemampuan kreatif dengan tingkat yang berbeda-beda. Tidak ada orang yang sama sekali tidak memiliki kreativitas, dan yang diperlukan adalah bagaimanakah mengembangkan kreativitas tersebut."

Munandar (1999:47-48) mengemukakan beberapa perumusan mengenai kreativitas yang merupakan kesimpulan dari para ahli mengenai kreativitas, yaitu sebagai berikut.

Pertama, kreativitas adalah kemampuan untuk membuat kombinasi baru, berdasarkan data, informasi, atau unsur-unsur yang ada.

Kedua, kreativitas (berpikir kreatif atau berpikir divergen) adalah kemampuan -berdasarkan data atau informasi yang tersediamenemukan banyak kemungkinan jawaban terhadap suatu masalah, dimana penekanannya adalah pada kuantitas, ketepatgunaan, dan keragaman jawaban.

Peningkatan kreativitas siswa dalam pembelajaran menulis naskah drama perlu dilakukan dengan jalan praktik, bukan dengan jalan memberitahu siswa mengenai arti kreatif maupun kreativitas. Terkait dengan hal itu, diperlukan sebuah model pembelajaran yang dapat meningkatkan kreativitas siswa dalam pembelajaran menulis naskah drama. Yunus (2015:33) menyatakan bahwa "masalah hanya sekadar alat untuk memicu gairah kreativitas yang dimiliki." Selain itu, Munandar (1999:48) menyatakan bahwa,

Makin banyak kemungkinan jawaban yang dapat diberikan terhadap suatu masalah makin kreatiflah seseorang. Tentu saja jawaban-jawaban itu harus sesuai dengan masalahnya. Jadi, tidak semata-mata banyaknya jawaban yang dapat diberikan yang menentukan kreativitas seseorang, tetapi juga kualitas atau mutu dari jawabannya.

Menilik fenomena di atas, penggunaan model pembelajaran dengan pemanfaatan masalah sebagai ciri utama diperlukan untuk meningkatkan kreativitas siswa dalam pembelajaran menulis naskah drama. Terkait dengan hal itu, penggunaan model pembelajaran berbasis masalah relevan dengan kebutuhan yang telah dikemukakan karena 
pemunculan masalah menjadi starting point dalam model pembelajaran berbasis masalah.

Hosnan (2014:298) mengemukakan bahwa pembelajaran berbasis masalah adalah pembelajaran yang menggunakan masalah nyata (autentik) yang tidak terstruktur (illstructured) dan bersifat terbuka sebagai konteks peserta didik untuk mengembangkan keterampilan menyelesaikan masalah dan berpikir kritis serta sekaligus membangun pengetahuan baru.

Berdasarkan permasalahan di atas, dilakukan penelitian mengenai kreativitas siswa dalam pembelajaran menulis naskah drama, yang pada akhirnya bertujuan untuk meningkatkan kreativitas siswa dalam pembelajaran menulis naskah drama. Selain untuk meningkatkan kreativitas siswa dalam pembelajaran menulis naskah drama yang menjadi pokok utama dalam penelitian ini, penelitian ini pun bertujuan untuk meningkatkan efektivitas pembelajaran menulis naskah drama, dan minat siswa dalam pembelajaran menulis naskah drama. Hasil dari penelitian ini diharapkan akan menguntungkan bagi berbagai pihak, baik guru, siswa, peneliti, maupun bagi pengembangan ilmu selanjutnya.

\section{METODE PENELITIAN}

Metode yang digunakan dalam penelitian ini adalah metode Penelitian Tindakan Kelas (PTK) atau dalam istilah bahasa Inggris disebut Classroom Action Research (CAR). Subjek penelitian ini adalah siswa kelas XI IPA 2 yang berjumlah 44 orang, terdiri atas 30 orang perempuan dan 14 orang laki-laki.

Penelitian ini dilaksanakan dalam tiga siklus. Setiap siklus meliputi empat tahapan, yaitu perencanaan, pelaksanaan, observasi, dan refleksi. Tindakan yang dilakukan untuk memecahkan masalah penelitian adalah dengan menerapkan model pembelajaran berbasis masalah dengan langkah-langkah yaitu orientasi siswa pada masalah, mengorganisasikan siswa untuk belajar, membimbing penyelidikan individual dan kelompok, mengembangkan dan menyajikan hasil karya, dan menganalisis dan mengevaluasi proses pemecahan masalahnya.

Instrumen yang digunakan dalam penelitian ini yaitu tes, angket, dan lembar observasi. Tes digunakan untuk mengetahui kreativitas siswa pada setiap siklusobservasi gunakan untuk mengamati efektivitas pembelajaran menulis naskah drama pada setiap siklus, dan angket digunakan untuk mengetahui minat siswa dalam pembelajaran menulis naskah drama pada setiap siklus.

Dalam penelitian ini, ditetapkan beberapa indikator keberhasilan tindakan. Indikator keberhasilan dalam penelitian ini terkait dengan kreativitas siswa dalam pem-belajaran menulis naskah drama, efektivitas pembelajaran menulis naskah drama, dan minat siswa dalam pembelajaran menulis naskah drama. Indikator keberhasilan untuk kreativitas siswa yaitu apabila dari total keseluruhan siswa, $85 \%$ siswa mencapai nilai Kriteria Ketuntasan Minimum (KKM) dan dikategorikan tuntas. Indikator keberhasilan efektivitas pembelajaran yaitu apabila dari segi aktivitas guru dan siswa dikategorikan sangat baik, yaitu mencapai nilai rata-rata 2,50. Adapun indikator keberhasilan minat siswa yaitu apabila nilai rata-rata angket yang diperoleh dikategorikan ke dalam sudah membudaya (SM).

\section{HASIL PENELITIAN}

Penelitian ini dilaksanakan dalam tiga siklus. Pembelajaran siklus I berlangsung dalam dua kali pertemuan, begitu pun pada pembelajaran siklus II dan pembelajaran siklus III. Setiap pertemuan dilakukan dengan tiga kegiatan yaitu kegiatan awal, kegiatan inti, dan kegiatan penutup. Dalam setiap pertemuan digunakan model pembelajaran berbasis masalah. 


\section{Siklus I}

Pembelajaran siklus I dirasakan belum optimal, baik itu dari kreativitas siswa, efektivitas, maupun minat siswa dalam pembelajaran menulis naskah drama. Kreativitas siswa dalam pembelajaran menulis naskah drama pada siklus I masih belum optimal terlihat dari nilai rata-rata yang diperoleh pada siklus I, yaitu 75,95. Selain itu, berdasarkan Kriteria Ketuntasan Minimum (KKM) yang telah ditentukan yaitu 75, siswa yang belum mencapai Kriteria Ketuntasan Minimum (KKM) sebanyak 19 orang siswa $(43,18 \%)$ dan dikategorikan tidak tuntas, sedangkan siswa yang sudah mencapai Kriteria Ketuntasan Minimum (KKM) sebanyak 25 orang siswa $(56,82 \%)$ dan dikategorikan tuntas. Jadi, berdasarkan indikator keberhasilan yang telah ditetapkan, pada siklus I belum mencapai apa yang diharapkan karena siswa yang dikategorikan tuntas hanya mencapai $56,82 \%$ dari target $85 \%$.

Pada siklus I, nilai rata-rata aspek yang dinilai dalam kreativitas siswa pun belum mencapai hasil yang maksimal. Nilai rata-rata elaborasi tema adalah 5,73 dari skor ideal 10 . Nilai rata-rata aspek kelancaran dalam mengungkapkan latar adalah 5,64 dari skor ideal 10. Nilai rata-rata aspek kelancaran dalam mengungkapkan alur adalah 10,00 dari skor ideal 15. Nilai rata-rata aspek kelancaran dalam mengungkapkan unsur-unsur yang diberikan adalah 7,50 dari skor ideal 15 . Adapun nilai rata-rata aspek keluwesan dalam mengungkapkan tokoh sudah cukup baik, sebab dari skor ideal 10 nilai rata-ratanya adalah 9,82. Begitu pun pada aspek dialog, nilai rata-ratanya sudah cukup baik yaitu 9,32 dari skor ideal 10. Aspek kelancaran dalam mengungkapkan petunjuk teknis pun sudah cukup baik, yaitu 9,20 dari skor ideal 10 . Selain itu, aspek orisinalitas isi cerita pun sudah cukup baik karena nilai rata-ratanya adalah 18,75 dari skor ideal 20.

Efektivitas pembelajaran menulis naskah drama dengan menggunakan model pembelajaran berbasis masalah pada pembelajaran siklus I belum memperoleh hasil yang optimal, karena berdasarkan datadata yang telah diperoleh nilai rata-rata aktivitas guru selama siklus I adalah 2,45 dan dibulatkan menjadi 2. Nilai 2 tersebut termasuk ke dalam kategori cukup. Adapun nilai rata-rata efektivitas pembelajaran dari segi aktivitas siswa selama siklus I adalah 2,05 dan dibulatkan menjadi 2. Nilai 2 tersebut termasuk ke dalam kategori cukup. Jadi, berdasarkan indikator keberhasilan yang telah ditetapkan, efektivitas pembelajaran pada siklus I belum mencapai kategori sangat baik karena efektivitas pembelajaran pada siklus I masih dikategorikan cukup, baik itu dari segi aktivitas siswa maupun guru.

Minat siswa pada siklus I belum mencapai hasil yang maksimal. Hal tersebut terlihat dari nilai rata-rata angket yang diperoleh pada siklus I, yaitu 78,92 dengan keterangan mulai berkembang (MB), yang artinya minat siswa dalam pembelajaran menulis naskah drama pada siklus I baru mulai berkembang. Jadi, berdasarkan indikator keberhasilan minat, pada siklus I belum mencapai target yang diharapkan karena minat siswa baru mulai berkembang (MB), belum membudaya (SM).

Berdasarkan data-data yang diperoleh pada siklus I, baik itu mengenai kreativitas siswa, efektivitas pembelajaran, dan minat siswa dalam pembelajaran, maka penelitian ini dilanjutkan pada siklus II.

\section{Siklus II}

Kreativitas siswa dalam pembelajaran menulis naskah drama pada siklus II sudah cukup baik apabila dibandingkan dengan kreativitas siswa dalam pembelajaran menulis naskah drama pada siklus I. Hal tersebut terlihat dari nilai rata-rata yang diperoleh pada siklus II yaitu 86,59. Selain itu, dari total keseluruhan siswa yaitu 44 orang siswa $(100 \%)$, sebanyak 36 orang siswa $(81,82 \%)$ sudah mencapai Kriteria Ketuntasan Minimum (KKM) dan dikategorikan tuntas, sedangkan sebanyak 8 orang siswa $(18,18 \%)$ 
belum mencapai Kriteria Ketuntasan Minimum (KKM) dan dikategorikan tidak tuntas. Meskipun mengalami peningkatan dari siklus sebelumnya, tetapi berdasarkan indikator keberhasilan yang telah ditetapkan, pada siklus II belum mencapai hasil yang diharapkan karena siswa yang dikategorikan tuntas baru mencapai $81,82 \%$ dari target yang telah ditetapkan yaitu $85 \%$.

Berdasarkan nilai rata-rata aspek yang dinilai, diketahui bahwa masih ada beberapa aspek yang belum mencapai nilai rata-rata yang maksimal. Nilai rata-rata elaborasi tema masih belum maksimal karena dari skor ideal 10 nilai rata-ratanya hanya mencapai 7,77 . Nilai rata-rata kelancaran dalam mengungkapkan latar pun masih belum maksimal karena dari skor ideal 10 hanya mencapai 7,05. Selain itu, nilai rata-rata kelancaran dalam mengungkapkan unsur-unsur yang diberikan pun masih belum maksimal karena dari skor ideal 15 baru mencapai nilai ratarata 11,02 . Tidak hanya itu, nilai rata-rata kelancaran dalam mengungkapkan alur pun masih kurang maksimal yaitu 11,93 dari skor ideal 15. Adapun aspek keluwesan dalam mengungkapkan tokoh sudah cukup baik karena dari skor ideal 10 nilai rata-ratanya adalah 9,95. Begitu pun aspek kelancaran dalam mengungkapkan dialog, petunjuk teknis, serta orisinalitas isi cerita sudah cukup baik karena sudah hampir mencapai skor ideal. Nilai rata-rata 9,55 untuk kelancaran dalam mengungkapkan dialog dari skor ideal 10. Nilai rata-rata 9,89 untuk kelancaran dalam mengungkapkan petunjuk teknis dari skor ideal 10. Nilai rata-rata 19,43 untuk orisinalitas isi cerita dari skor ideal 20.

Efektivitas pembelajaran menulis naskah drama dengan menggunakan model pembelajaran berbasis masalah pada siklus II mengalami peningkatan dari siklus I. Nilai rata-rata efektivitas pembelajaran dari segi aktivitas guru selama siklus II adalah 3,27 dan dibulatkan menjadi 3. Nilai 3 tersebut termasuk ke dalam kategori baik. Adapun nilai rata-rata efektivitas pembelajaran dari segi aktivitas siswa selama siklus II adalah 3 dan dibulatkan menjadi 3. Nilai tersebut termasuk ke dalam kategori baik. Jadi, berdasarkan indikator keberhasilan yang telah ditetapkan, efektivitas pembelajaran pada siklus II belum mencapai kategori sangat baik karena efektivitas pembelajaran pada siklus II baru dikategorikan baik.

Minat siswa pada siklus II dikategorikan mulai berkembang. Hal tersebut terlihat dari nilai rata-rata angket yang diperoleh pada siklus II, yaitu 85,91 dengan keterangan mulai berkembang (MB). Meskipun keterangan angket siklus I dan siklus II sama, yaitu mulai berkembang (MB), tetapi pada dasarnya ada peningkatan dari siklus I ke siklus II. Hal tersebut terlihat dari perbedaan nilai rata-rata yang diperoleh. Pada siklus I nilai rata-ratanya adalah 78,92 , sedangkan pada siklus II nilai rata-ratanya adalah 85,91. Jadi, berdasarkan indikator keberhasilan minat, pada siklus I belum mencapai target yang diharapkan karena minat siswa baru mulai berkembang (MB), belum membudaya (SM).

Berdasarkan data-data yang diperoleh pada siklus III, baik itu mengenai kreativitas siswa, efektivitas pembelajaran, dan minat siswa dalam pembelajaran, maka penelitian ini dilanjutkan pada siklus III.

\section{Siklus III}

Pembelajaran siklus III sudah sangat baik. Hal tersebut terlihat dari data-data yang diperoleh, baik mengenai kreativitas siswa, efektivitas, maupun minat siswa dalam pembelajaran menulis naskah drama.

Kreativitas siswa dalam pembelajaran menulis naskah drama pada siklus III sudah sangat baik. Hal tersebut terlihat dari nilai rata-rata yang diperoleh, yaitu 95,45. Selain itu, berdasarkan Kriteria Ketuntasan Minimum (KKM) yang telah ditetapkan yaitu 75 , semua siswa yaitu 44 orang siswa (100\%) sudah memenuhi Kriteria Ketuntasan Minimum (KKM) dan dikategorikan tuntas. Jadi, berdasarkan indikator keberhasilan yang 
telah ditetapkan, pada siklus III semua siswa yaitu $100 \%$ siswa sudah mencapai apa yang diharapkan, bahkan melampaui target yang telah ditetapkan, yaitu $85 \%$ siswa mencapai Kriteria Ketuntasan Minimum (KKM) dan dikategorikan tuntas .

Nilai rata-rata aspek yang dinilai pun sudah sangat baik. Nilai rata-rata elaborasi tema adalah 9,64 dari skor ideal 10. Nilai rata-rata aspek keluwesan dalam mengungkapkan tokoh adalah 10,00 dari skor ideal 10. Nilai rata-rata aspek kelancaran dalam mengungkapkan unsur-unsur yang diberikan adalah 13,86 dari skor ideal 15. Nilai rata-rata aspek kelancaran dalam mengungkapkan alur adalah 13,75 dari skor ideal 15 . Nilai rata-rata aspek kelancaran dalam mengungkapkan latar adalah 8,64 dari skor ideal 10. Nilai rata-rata aspek kelancaran dalam mengungkapkan dialog adalah 9,91 dari skor ideal 10. Nilai rata-rata aspek kelancaran dalam mengungkapkan petunjuk teknis adalah 10,00 dari skor ideal 10. Nilai rata-rata aspek orisinalitas isi cerita adalah 19,66 dari skor ideal 20.

Efektivitas pembelajaran menulis naskah drama pada pembelajaran siklus III sudah memperoleh hasil maksimal, sebab berdasarkan data-data terkumpul nilai rata-rata efektivitas pembelajaran menulis naskah drama dari segi aktivitas guru selama siklus III adalah 3,82 dan dibulatkan menjadi 4 . Nilai 4 tersebut termasuk ke dalam kategori sangat baik. Adapun nilai rata-rata efektivitas pembelajaran dari segi aktivitas siswa selama siklus III adalah 3,68 dan dibulatkan menjadi 4. Nilai 4 tersebut termasuk ke dalam kategori sangat baik. Selain itu, keadaan kelas pun sudah kondusif.

Minat siswa dalam pada pembelajaran siklus III sudah membudaya. Hal tersebut terlihat dari nilai rata-rata angket yang diperoleh pada siklus III, yaitu 92,39 dengan keterangan sudah membudaya (SM). Jadi, berdasarkan indikator keberhasilan minat, pada siklus III sudah mencapai target yang diharapkan karena minat siswa baru sudah membudaya (SM).

Selain itu, pada siklus III, minat siswa sudah diekspresikan pada tiga kategori, yaitu diekspresikan melalui pernyataan suka, senang, dan antusias terhadap pembelajaran menulis naskah drama, diekspresikan melalui keterlibatannya dalam pembelajaran menulis naskah drama, serta diekspresikan oleh perhatiannya yang lebih terhadap pembel-ajaran menulis naskah drama dan hal itu sudah mencakup keseluruhan siswa. Hal tersebut terlihat dari alternatif jawaban yang dipilih siswa. Tidak ada siswa yang memilih jawaban negatif untuk 10 pernyataan positif, yaitu tidak setuju dan sangat tidak setuju. Dari total keseluruhan siswa, yaitu 44 orang siswa memilih jawaban positif terhadap 10 pernyataan positif, yaitu setuju dan sangat setuju.

\section{PEMBAHASAN}

\section{Kreativitas}

Kreativitas siswa dalam pembelajaran menulis naskah drama mengalami peningkatan yang cukup signifikan pada setiap siklus. Hal tersebut terlihat dari nilai rata-rata yang diperoleh pada setiap siklus. Nilai ratarata yang diperoleh pada siklus I adalah 75,95, nilai rata-rata yang diperoleh pada siklus II adalah 86,59, dan nilai rata-rata yang diperoleh pada siklus III adalah 95,45. Selain itu, kreativitas siswa pada setiap siklus meningkat pun terlihat dari nilai tertinggi dan nilai terendah yang diperoleh pada setiap siklus. Pada siklus I, nilai terendahnya adalah 59, sedangkan pada siklus II nilai terendahnya adalah 73, adapun pada siklus III nilai terendahnya adalah 88. Pada siklus I, nilai tertingginya adalah 98, pada siklus II adalah 100, dan pada siklus III nilai tertingginya adalah 100 .

Berdasarkan Kriteria Ketuntasan Minimum (KKM) yang telah ditetapkan yaitu 75, pada siklus I sebanyak 25 orang siswa $(56,82 \%)$ telah mencapai nilai Kriteria Ketuntasan Minimum (KKM) dan dikategorikan tuntas, adapun sebanyak 19 orang 
siswa $(43,18 \%)$ belum mencapai nilai Kriteria Ketuntasan Minimum (KKM) dan dikategorikan tidak tuntas. Pada siklus II, siswa yang mencapai nilai Kriteria Ketuntasan Minimum (KKM) dan dikategorikan tuntas meningkat menjadi 36 orang siswa $(81,82 \%)$ dan siswa yang belum mencapai nilai Kriteria Ketuntasan Minimum (KKM) menurun menjadi 8 orang siswa $(18,18 \%)$. Adapun pada siklus III yaitu 44 orang siswa (100\%) sudah mencapai nilai Kriteria Ketuntasan Minimum (KKM).

Selain nilai rata-rata, nilai terendah, nilai tertingi, dan pencapaian nilai Kriteria Ketuntasan Minimum (KKM), nilai yang tersebar pada setiap siklus pun mengalami peningkatan. Pada siklus I, dari total keseluruhan siswa yaitu 44 orang siswa $(100 \%), 1$ orang siswa $(2,27 \%)$ mendapatkan nilai 98, 1 orang siswa $(2,27 \%)$ nilai 93 , sebanyak 8 orang siswa $(18.18 \%)$ mendapatkan nilai 83 , sebanyak 4 orang siswa $(9,09 \%)$ mendapatkan nilai 82 , sebanyak 11 orang siswa (25\%) mendapatkan nilai 78 , sebanyak 4 orang siswa $(9,09 \%)$ mendapatkan nilai 73 , sebanyak 1 orang siswa $(2,27 \%)$ mendapatkan nilai 70 , sebanyak 11 orang siswa $(25 \%)$ mendapatkan nilai 68 , sebanyak 2 orang siswa $(4,55 \%)$ mendapatkan nilai 66, dan sebanyak 1 orang siswa $(2,27 \%)$ mendapatkan nilai 59 .

Pada siklus II, dari total keseluruhan siswa yaitu 44 orang siswa (100\%), sebanyak 1 orang siswa $(2,27 \%)$ mendapatkan nilai 100 , sebanyak 5 orang siswa $(11,36 \%)$ mendapatkan nilai 98, sebanyak 5 orang siswa $(11,36 \%)$ mendapatkan nilai 93, sebanyak 9 orang siswa $(20,45 \%)$ mendapatkan nilai 89 , sebanyak 8 orang siswa $(18,18 \%)$ mendapatkan nilai 88 , sebanyak 4 orang siswa $(9,09 \%)$ mendapatkan nilai 86 , sebanyak 2 orang siswa $(4,55 \%)$ mendapatkan nilai 83 , sebanyak 2 orang siswa $(4,55 \%)$ mendapatkan nilai 78 , dan sebanyak 8 orang siswa $(18,18 \%)$ mendapat nilai 73 .

Pada siklus III, dari total keseluruhan siswa yaitu 44 orang siswa (100\%), sebanyak 15 orang siswa $(34,09 \%)$ mendapatkan nilai
100 , sebanyak 10 orang siswa $(22,73 \%)$ mendapatkan nilai 98, sebanyak 3 orang siswa $(6,82 \%)$ mendapatkan nilai 96 , sebanyak 4 orang siswa $(9,09 \%)$ mendapatkan nilai 93, sebanyak 4 orang siswa $(9,09 \%)$ mendapatkan nilai 89 , sebanyak 8 orang siswa $(18,18 \%)$ mendapatkan nilai 88 .

Nilai rata-rata yang diperoleh pada setiap aspek yang dinilai pun mengalami peningkatan pada setiap siklusnya. Nilai ratarata aspek elaborasi tema pada siklus I adalah 5,73 , sedangkan nilai rata-rata elaborasi tema pada siklus II adalah 7,77 , adapun nilai ratarata elaborasi tema pada siklus III adalah 9,64. Nilai rata-rata aspek keluwesan dalam mengungkapkan tokoh pada siklus I adalah 9,82, sedangkan pada siklus II nilai rataratanya adalah 9,95, adapun pada siklus III nilai rata-ratanya adalah 10,00 . Nilai rata-rata aspek kelancaran dalam mengungkapkan unsur-unsur yang diberikan pada siklus I adalah 7,50, sedangkan pada siklus II nilai rata-ratanya adalah 11,02 , adapun pada siklus III nilai rata-ratanya adalah 13,86 . Nilai ratarata aspek kelancaran dalam mengungkapkan alur pada siklus I adalah 10,00, pada siklus II adalah 11,93 dan pada siklus III adalah 13,75. Nilai rata-rata aspek kelancaran dalam mengungkapkan latar pada siklus I adalah 5,64, sedangkan pada siklus II nilai rata-ratanya adalah 7,05, adapun pada siklus III nilai rataratanya adalah 8,64. Nilai rata-rata aspek kelancaran dalam mengungkapkan dialog pada siklus I adalah 9,32, sedangkan pada siklus II nilai rata-ratanya adalah 9,55, adapun pada siklus III nilai rata-ratanya adalah 9,91. Nilai rata-rata aspek kelancaran dalam mengungkapkan petunjuk teknis pada siklus I adalah 9,20, sedangkan pada siklus II nilai rata-ratanya adalah 9,89 , adapun pada siklus III nilai rata-ratanya adalah 10,00. Nilai rata-rata aspek orisinalitas isi cerita pada siklus I adalah 18,75, sedangkan pada siklus II nilai rata-ratanya adalah 19,43 , adapun pada siklus III nilai rata-ratanya adalah 19,66. 


\section{Efektivitas}

Efektivitas pembelajaran menulis naskah drama dengan menggunakan model pembelajaran berbasis masalah pada pembelajaran siklus I belum memperoleh hasil yang optimal, karena berdasarkan data-data yang telah diperoleh nilai rata-rata aktivitas guru selama siklus I adalah 2,45 dan dibulatkan menjadi 2. Nilai 2 tersebut termasuk ke dalam kategori cukup. Adapun nilai rata-rata efektivitas pembelajaran dari segi aktivitas siswa selama siklus I adalah 2,05 dan dibulatkan menjadi 2. Nilai 2 tersebut termasuk ke dalam kategori cukup.

Efektivitas pembelajaran menulis naskah drama dengan menggunakan model pembelajaran berbasis masalah pada siklus II mengalami peningkatan dari siklus I. Nilai rata-rata efektivitas pembelajaran dari segi aktivitas guru selama siklus II adalah 3,27 dan dibulatkan menjadi 3. Nilai 3 tersebut termasuk ke dalam kategori baik. Adapun nilai rata-rata efektivitas pembelajaran dari segi aktivitas siswa selama siklus II adalah 3 dan dibulatkan menjadi 3. Nilai tersebut termasuk ke dalam kategori baik. Jadi, berdasarkan indikator keberhasilan yang telah ditetapkan, efektivitas pembelajaran pada siklus III sudah mencapai target yang diharapkan karena efektivitas pembelajaran pada siklus II baru dikategorikan baik.

Efektivitas pembelajaran menulis naskah drama dengan menggunakan model pembelajaran berbasis masalah pada pembelajaran siklus III mengalami peningkatan dari siklus II. Nilai rata-rata efektivitas pembelajaran dari segi aktivitas guru selama siklus III adalah 3,82 dan dibulatkan menjadi 4. Nilai 4 tersebut termasuk ke dalam kategori sangat baik. Adapun nilai rata-rata efektivitas pembelajaran dari segi aktivitas siswa selama siklus III adalah 3,68 dan dibulatkan menjadi 4. Nilai 4 tersebut termasuk ke dalam kategori sangat baik.

\section{Minat}

Minat siswa dalam pembelajaran menulis naskah drama pada setiap siklusnya mengalami peningkatan. Hal tersebut terlihat dari nilai rata-rata angket yang diperoleh pada setiap siklus. Nilai rata-rata angket mengenai minat siswa pada siklus I adalah 78,92 dengan keterangan mulai berkembang (MB). Nilai rata-rata angket mengenai minat siswa pada siklus II adalah 85,91 dengan keterangan mulai berkembang (MB). Nilai ratarata angket mengenai minat siswa pada siklus III adalah 92,73 dengan keterangan sudah membudaya (SM). Meskipun keterangan angket siklus I dan siklus II sama, yaitu mulai berkembang (MB), tetapi pada dasarnya ada peningkatan dari siklus I ke siklus II. Hal tersebut terlihat dari perbedaan nilai rata-rata yang diperoleh. Pada siklus I nilai rataratanya adalah 78,92 , sedangkan pada siklus II nilai rata-ratanya adalah 85,91 .

Selain terlihat dari nilai rata-rata yang diperoleh, minat siswa mengalami peningkatan pada setiap siklus pun terlihat dari kategori minat yang diperoleh pada setiap siklus. Pada siklus 1 diketahui bahwa dari total keseluruhan siswa yaitu 44 orang siswa $(100 \%)$, minat 2 orang siswa $(4,55 \%)$ dikategorikan belum terlihat (BT), minat 16 orang siswa $(36,36 \%)$ dikategorikan mulai terlihat, minat 14 orang siswa $(31,82 \%)$ dikategorikan mulai berkembang (MB), dan minat 12 orang siswa $(27,27 \%)$ dikategorikan sudah membudaya (SM). Pada siklus II, dari total keseluruhan siswa yaitu 44 orang siswa (100\%), minat 7 orang siswa $(15,91 \%)$ dikategorikan mulai terlihat (MT), minat 18 orang siswa $(40,91 \%)$ dikategorikan mulai berkembang (MB), dan minat 19 orang siswa $(43,18 \%)$ dikategorikan sudah membudaya (SM). Pada siklus III, dari total keseluruhan siswa yaitu 44 orang siswa (100\%), minat 18 orang siswa $(40,91 \%)$ dikategorikan mulai berkembang $(\mathrm{MB})$, sedangkan minat 26 orang siswa $(59,09 \%)$ dikategorikan sudah membudaya (SM). 


\section{SIMPULAN}

Berdasarkan data-data yang diperoleh, diketahui bahwa model pembelajaran berbasis masalah dapat meningkatkan kreativitas siswa dalam pembelajaran menulis naskah drama, efektivitas pembelajaran menulis naskah drama, dan minat siswa dalam pembelajaran menulis naskah. Kreativitas siswa mengalami peningkatan terlihat dari nilai rata-rata yang diperoleh pada setiap siklus, yaitu pada siklus I nilai rata-rata kreativitas siswa adalah 75,95, sedangkan pada siklus II nilai rata-ratanya adalah 86,59 , adapun pada siklus III nilai rata-ratanya adalah 95,45 .

Berdasarkan Kriteria Ketuntasan Minimum (KKM) yang telah ditetapkan yaitu 75 , pada siklus I dari total keseluruhan siswa yaitu 44 orang siswa (100\%), sebanyak 25 orang siswa $(56,82 \%)$ sudah mencapai Kriteria Ketuntasan Minimum (KKM) dan dikategorikan tuntas, sedangkan sebanyak 19 orang siswa $(43,18 \%)$ belum mencapai Kriteria Ketuntasan Minimum (KKM) dan dikategorikan tidak tuntas. Pada siklus II, siswa yang sudah mencapai Kriteria Ketuntasan Minimum (KKM) meningkat menjadi 36 orang siswa $(81,82 \%)$ dan dikategorikan tuntas, sedangkan siswa yang belum mencapai Kriteria Ketuntasan Minimum (KKM) sebanyak 8 orang siswa $(18,18 \%)$. Pada siklus III, sebanyak 44 orang siswa (100\%) sudah mencapai Kriteria Ketuntasan Minimum (KKM), dan dikategorikan tuntas.

Efektivitas pembelajaran menulis naskah drama pun mengalami peningkatan. Berdasarkan data-data yang diperoleh, nilai rata-rata aktivitas guru selama siklus I adalah 2,45 dan dibulatkan menjadi 2. Nilai 2 tersebut termasuk ke dalam kategori cukup. Adapun nilai rata-rata efektivitas pembelajaran dari segi aktivitas siswa selama siklus I adalah 2,05 dan dibulatkan menjadi 2. Nilai 2 tersebut termasuk ke dalam kategori cukup.

Pada siklus II, efektivitas pembelajaran menulis naskah drama dengan menggunakan model pembelajaran berbasis masalah mengalami peningkatan dari siklus I. Nilai rata-rata efektivitas pembelajaran dari segi aktivitas guru selama siklus II adalah 3,27 dan dibulatkan menjadi 3. Nilai 3 tersebut termasuk ke dalam kategori baik. Adapun nilai rata-rata efektivitas pembelajaran dari segi aktivitas siswa selama siklus II adalah 3 termasuk ke dalam kategori baik.

Pada siklus III, efektivitas pembelajaran menulis naskah drama dengan menggunakan model pembelajaran berbasis masalah pun mengalami peningkatan dari siklus II. Nilai rata-rata efektivitas pembelajaran dari segi aktivitas guru selama siklus III adalah 3,82 dan dibulatkan menjadi 4 . Nilai 4 tersebut termasuk ke dalam kategori sangat baik. Adapun nilai rata-rata efektivitas pembelajaran dari segi aktivitas siswa selama siklus III adalah 3,68 dan dibulatkan menjadi 4 . Nilai 4 tersebut termasuk ke dalam kategori sangat baik. Selain itu, perhatian dan keaktifan siswa pun meningkat pada setiap siklusnya. Hal tersebut terlihat dari frekuensi siswa yang memperhatikan, bertanya, dan menjawab pertanyaan dari guru. Kekondusifan kelas dari setiap siklus pun selalu mengalami peningkatan.

Selain kreativitas siswa dan efektifitas pembelajaran yang mengalami peningkatan pada setiap siklusnya, minat siswa dalam pembelajaran menulis naskah drama dengan menggunakan model pembelajaran berbasis masalah pun mengalami peningkatan pada setiap siklusnya. Hal tersebut terlihat dari nilai rata-rata yang diperoleh pada setiap siklus. Nilai rata-rata angket mengenai minat siswa pada siklus I adalah 78,92 dengan keterangan mulai berkembang (MB). Nilai rata-rata angket mengenai minat siswa pada siklus II adalah 85,91 dengan keterangan mulai berkembang (MB). Nilai rata-rata angket mengenai minat siswa pada siklus III adalah 92,39 dengan keterangan sudah membudaya (SM).

Saran yang dapat disampaikan untuk sekolah yaitu hendaknya agar terus 
meningkatkan kreativitas siswa dalam setiap pembelajaran, khususnya dalam pembelajaran menulis naskah drama karena kreativitas diperlukan untuk menjawab tantangan global yang semakin hari semakin berkembang. Adapun saran yang dapat disampaikan pada siswa yaitu hendaknya siswa selalu memotivasi diri untuk mengeluarkan segenap kemampuan yang dimiliki untuk menumbuhkembangkan potensi yang ada, termasuk kreativitas yang dimiliki karena pada dasarnya semua orang memiliki potensi untuk dapat meningkatkan kualitas diri.

\section{DAFTAR PUSTAKA}

Hosnan. 2014. Pendekatan Saintifik dan Kontekstual dalam Pembelajaran Abad 21. Bogor: Ghalia Indonesia.

Munandar, Utami. 1999. Mengembangkan Bakat dan Kreativitas Anak Sekolah. Jakarta: PT Gramedia Widiasarana Indonesia.

Supriadi, Dedi. 1994. Kreativitas, Kebudayaan dan Perkembangan IPTEK. Bandung: Alfabeta.

Waluyo, Herman J. 2001. Drama dan Teori Pengajarannya. Yogyakarta: Hanindita Graha Widia.

Yunus, Syarifudin. 2015. Kompetensi Menulis Kreatif. Bogor: Ghalia Indonesia. 